\title{
Analisis dan Perancangan Sistem Informasi Manajemen Aset Rumah Sakit Berbasis Spatial
}

\author{
FEIBE LAWALATA ${ }^{1}$, EKO SEDIYONO ${ }^{2}$ \\ 1,2Program Studi Magister Sistem Informasi, Fakultas Teknologi Informasi \\ Universitas Kristen Satya Wacana \\ Jl. Diponegoro 52-60, Salatiga \\ Email : 972018005@student.uksw.edu1, eko@uksw.edu²
}

\begin{abstract}
ABSTRAK
Pengelolaan aset di rumah sakit merupakan hal yang penting untuk dilakukan demi keberlangsungan dan peningkatan kualitas pelayanan dari rumah sakit tersebut. Pengelolaan aset dapat berupa pencatatan, perawatan, hingga pengelolaan lebih lanjut. Pencatatan informasi aset yang dimiliki oleh rumah sakit sangat penting untuk dilakukan, dengan adanya informasi yang didapat dari pencatatan data aset maka rumah sakit akan dapat mengetahui secara pasti aset apa saja dan berapa tepatnya jumlah aset yang dimiliki oleh rumah sakit. Sistem informasi ini akan dibuat dengan mengunakan GIS dan akan diolah dengan Quantum GIS ditampilkan menggunakan Web yang berbasis GIS. Dengan Web-GIS yang di bangun ini, akan lebih membantu rumah sakit dalam pengelolaan aset dimasa yang akan datang.
\end{abstract}

\section{Kata kunci: Manajemen aset, Quantum GIS, Web-GIS, Rumah Sakit}

\section{PENDAHULUAN}

Pada saat ini perkembangan teknologi informasi berkembang dengan sangat pesat, setiap instansi dipermudah dengan pengembangan aplikasi yang memudahkan dalam pembuatan laporan.

Sistem informasi manajemen aset bertujuan untuk mempermudah pengelolaan aset sehingga dapat mengahasilkan informasi terpercaya, dan up to date[1]. Organisasi mengumpulkan data yang semakin besar volumenya, setelah disimpan digudang data, kemudian diolah untuk proses analisis data dan dapat dijadikan sebagai alat bantu pengambilan keputusan strategis organisasi. Namun data yang ada tidak selalu digunakan sepenuhnya dan ada bagian yang belum dimanfaatkan yaitu komponen spasial.[2]

Pengelolaan aset di rumah sakit merupakan hal yang penting untuk dilakukan demi keberlangsungan dan peningkatan kualitas pelayanan dari rumah sakit tersebut. Pengelolaan aset dapat berupa pencatatan, perawatan, hingga pengelolaan lebih lanjut. Pencatatan informasi aset yang dimiliki oleh rumah sakit sangat penting untuk dilakukan, dengan adanya informasi yang didapat dari pencatatan data aset maka rumah sakit akan dapat mengetahui secara pasti aset apa saja dan berapa tepatnya jumlah aset yang dimiliki oleh rumah sakit, sekaligus dapat diketahui lokasinya.

Dengan data aset rumah sakit yang di spatialkan, kita dapat mengetahui ada berapa ruangan yang ada, disetiap ruangan terdapat barang (aset) apa saja, mengetahui jumlah barang di tiap ruangan, dan total harga set di tiap ruangan.

Rumah Sakit Umum GMIM Siloam Sonder merupakan rumah sakit yang dikelola oleh Yayasan Medika GMIM yang terletak di kabupaten Minahasa, rumah sakit ini memiliki aset yang didominasi dengan kebutuhan pasien berupa barang dan peralatan untuk melakukan tindakan. Salah satu aspek keberlangsungan rumah sakit adalah kinerja dari pengelolaan aset yang ada. 
Dengan melakukan pencatatan informasi detail dari barang ataupun peralatan akan memberikan gambaran kepada pemimpin untuk mengambil keputusan terhadap aset yang ada, juga dapat membantu rumah sakit dalam pengurusan akreditasi KARS mengenai hal kesesuaian mutu ISO 9001-2008 atau Joint Commission International(JCI) serta UU RI No. 44 Tahun 2009 tentang pengelolaan sarana, prasarana, dan peralatan agar dapat dikelola dengan baik, efektif dan efisien.

Untuk keperluan tersebut maka perlu dianalisis dan dirancang sistem informasi manajemen rumah sakit umum GMIM siloam sonder berbasis spatial yang mempunyai fitur yaitu : mencatat detail informasi atribut aset, dapat memonitor data aset, dan dapat memetakan letak aset yang ada.

\section{TINJAUAN PISTAKA}

\section{A. Sistem Informasi}

Sistem informasi adalah kerangka kerja yang mengkoordinasikan sumber daya (manusia, Komputer) untuk mengubah masukan (input) menjadi keluaran (informasi), guna mencapai sasaran-sasaran perusahaan [3]. Dengan membangun sistem informasi aset rumah sakit, pihak rumah sakit dapat mengetahui letak dari setiap aset yang ada dan jumlah aset di setiap ruangan.

\section{B. SIG Berbasis Web}

Sistem Informasi Geografis (SIG) berbasis web adalah sebuah aplikasi sistem informasi geografis yang dapat dijalankan dan diaplikasikan pada suatu web browser. Aplikasi tersebut bisa dijalankan dalam suatu jaringan global yaitu internet, dalam suatu jaringan local atau jaringan LAN dan dalam suatu suatu computer yang memiliki web server.[4] Dengan menggunakan ini, kita dapat memantau data aset secara realtime, kapanpun diperlukan.

\section{Quantum GIS}

Quantum GIS (QGIS) adalah cross-platform perangkat lunak bebas (open source) desktop pada sistem informasi geografis. Aplikasi ini dapat menyediakan data, melihat, mengedit, dan kemampuan analisis. Quantum GIS berjalan pada sistem operasi yang berbeda termasuk Mac OS X , Linux , UNIX , dan Microsoft Windows. Secara yuridis, QGIS sebagai perangkat lunak bebas aplikasi di bawah GPL (General Public License), dapat secara bebas dimodifikasi untuk melakukan tugas yang berbeda atau lebih khusus.[5]

Quantum GIS memungkinkan penggunaan shape files, pertanggungan, dan Geodatabases pribadi. MapInfo , PostGIS , dan beberapa format lain didukung di Quantum GIS. Pengolahan data aset rumah sakit akan di spasialkan menggunakan aplikasi Quantum GIS, dan di export menjadi Web GIS menggunakan fitur Leaflet yang ada di Quantum GIS.

\section{JSON}

JSON (JavaScript Object Notation) adalah format pertukaran data yang ringan, mudah dibaca dan ditulis oleh manusia, serta mudah diterjemahkan dan dibuat (generate) oleh komputer. Format ini dibuat berdasarkan bagian dari Bahasa Pemprograman JavaScript, Standar ECMA262 Edisi ke-3 - Desember 1999. JSON merupakan format teks yang tidak bergantung pada bahasa pemprograman apapun karena menggunakan gaya bahasa yang umum digunakan oleh programmer keluarga $\mathrm{C}$ termasuk C, C++, C\#, Java, JavaScript, Perl, Python dll. Oleh karena sifat-sifat tersebut, menjadikan JSON ideal sebagai bahasa pertukaran-data [6]. dalam pembuatan sistem informasi aset rumah sakit, kita akan menggunakan JSON. 


\section{METODE}

Alur pembuatan sistem informasi rumah sakit berbasis spasial, di mulai dari tahap pengambilan data aset rumah sakit, pihak rumah sakit memberikan data aset dalam format excel, kemudian data yang di dapat di olah sehingga dapat di masukan ke dalam atribut Quantum GIS.

Setelah data selesai di olah, tahap selanjutnya yaitu melakukan digitasi. Sebelum masuk dalam tahap digitasi, kita perlu menyiapkan shape file (.shp) kabupaten minahasa yang dapat di ambil secara gratis melalui web http://tanahair.indonesia.go.id, setelah file shp di dapatkan, kita masuk dalam tahap digitasi. Untuk mempermudah proses pembuatan shape file (.shp) rumah sakit, kita dapat menggunakan OpenLayers Plugin dalam aplikasi Quantum GIS untuk memanggil Google Satellite.

Setelah membuat shape file (.shp) rumah sakit, yang berupa polygon dan point kita akan memasukkan atribut ke dalam shape file (.shp) yang telah di bagi berdasarkan bangunan bangunan yang ada yaitu : kantor, ruangan_1, ruangan_2, dan ruangan_3. Setiap ruangan di masukkan atribut sesuai data excel yang telah di olah. Data tersebut merupakan data asset dari rumah sakit, yang berupa barang, jumlah barang dan jumlah total asset (rupiah).

Langkah selanjutnya yaitu meng-export data shape file (.shp) menjadi GeoJSON, kemudian melakukan pengkodean untuk membuat tampilan interface dari web sistem informasi asset rumah sakit. Setelah selesai melakukan pengkodean kita perlu membuat koneksi menggunakan xampp, sehingga Web-GIS dapat di panggil menggunakan browser.

Diagram alur pembuatan sistem informasi rumah sakit berbasis spasial dapat dilihat di gambar 1.

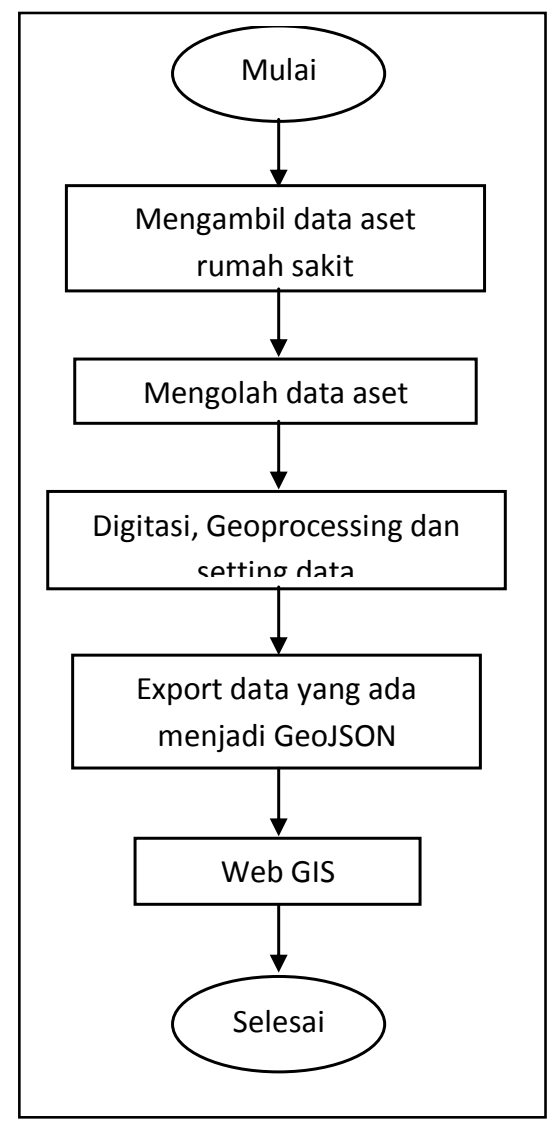

Gambar 1. Tahapan penelitian 


\section{HASIL DAN PEMBAHASAN}

Setelah semua tahap yang ada telah dilakukan, maka tampilan utama yang dihasilkan Web-GIS dapat dilihap pada gambar ke-2 di bawah ini :

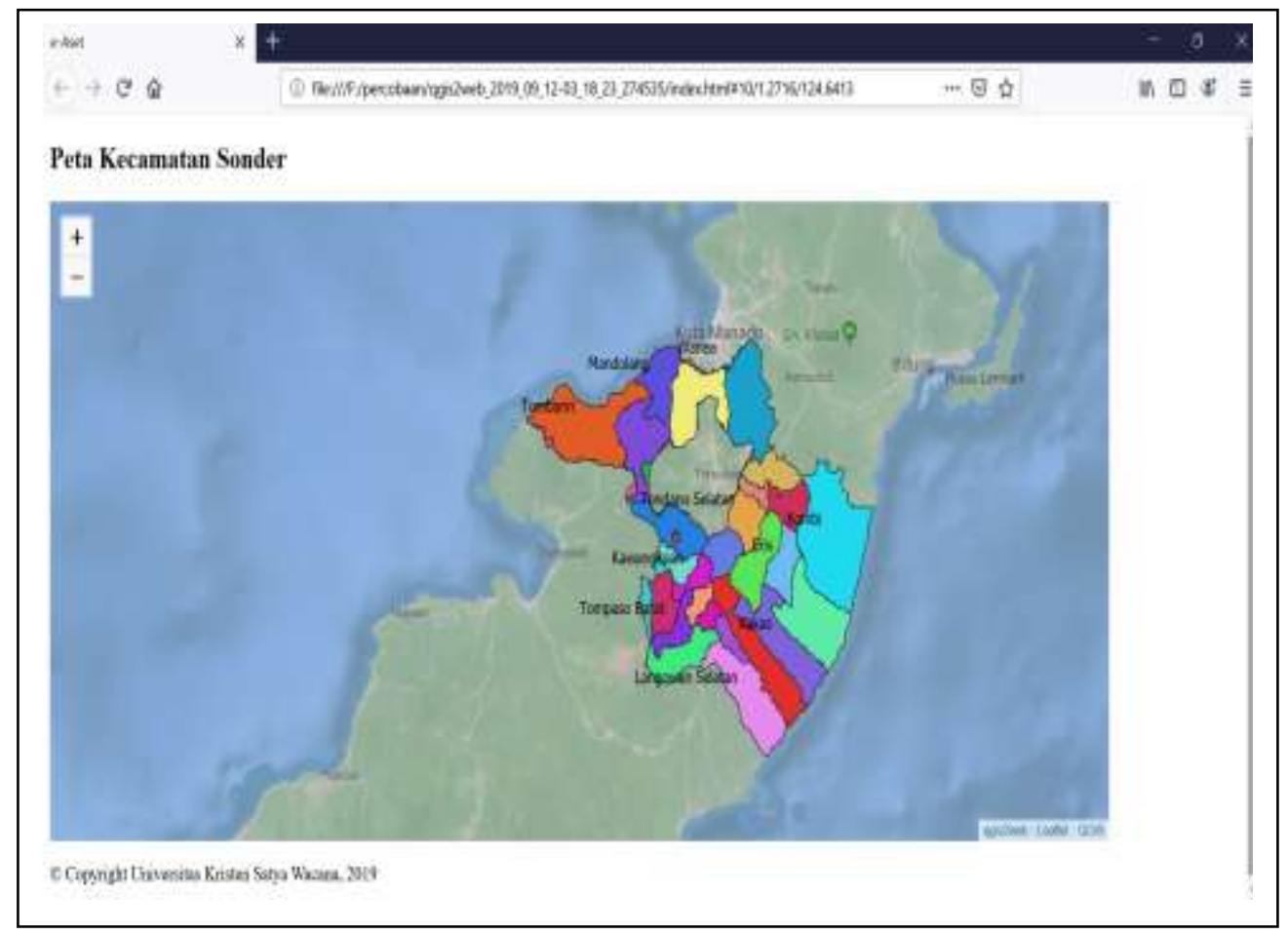

\section{Gambar 2. Tampilan Web-GIS}

Pada halaman utama menampilkan peta utama dari Kecamatan Sonder, yang dimana pada halaman tersebut terdapat legenda peda. Reference peta memiliki fungsi untuk menampilkan keseluruhan dari gambar peta utama, tool navigasi peta yaitu zoom in dan zoom out. Query berguna supaya kita dapat melihat informasi yang ada di dalam peta tersebut.

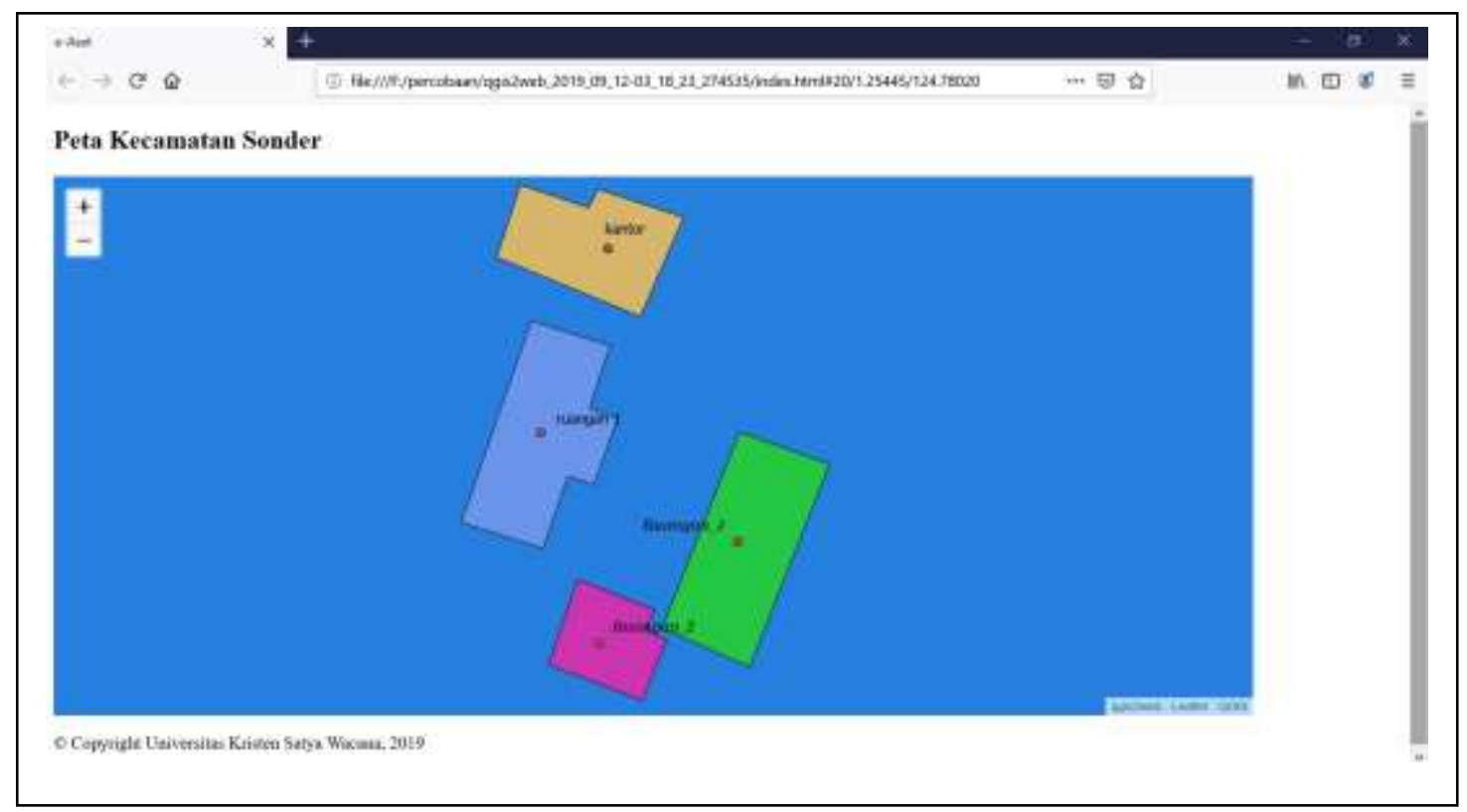

Gambar 3. Peta Bangunan Rumah Sakit 
Gambar 3 memuat peta letak bangunan rumah sakit yang terdiri atas bagunan kantor, ruangan_1, ruangan_2 dan ruangan_3. Dimana runagan_1 terdiri atas 2 ruangan rawat inap (Abraham 1 dan Abraham 2), UGD, Apotek dan Administrasi. Ruangan_2 yaitu, ruang rawat inap (Maria) khusus anak-anak. Dan Ruangan_3 yaitu ruang rawat inap (Ester) dan ruang rawat inap VIP.

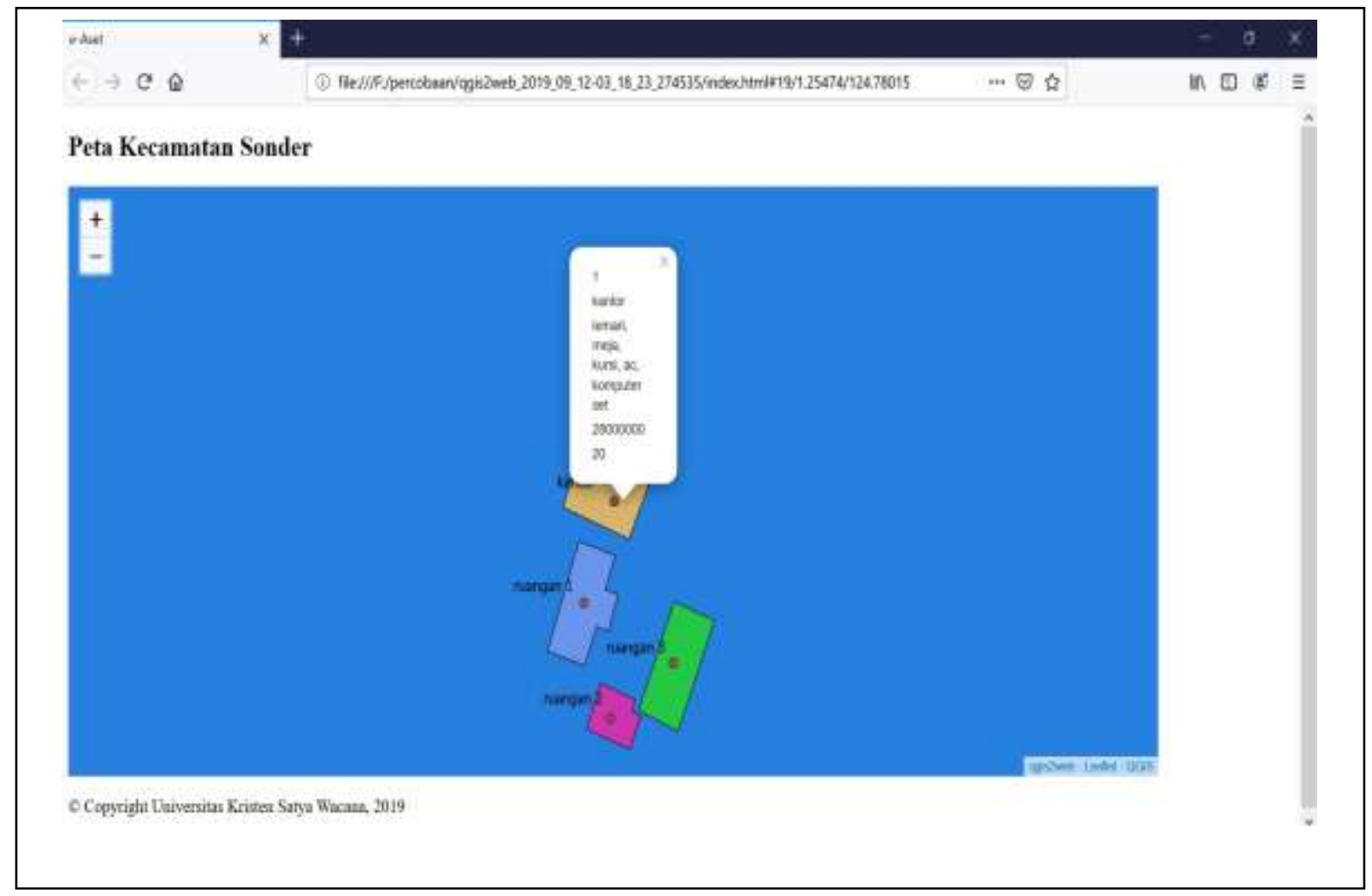

\section{Gambar 4. Informasi aset tiap bagunan}

Gambar 4 memuat informasi asset yang ada di setiap bangunan yang terdiri dari nama ruangan, nama barang, jumlah barang dan total jumlah aset yang ada (rupiah).

Sistem yang dibuat ini masih dalam bentuk prototype dasar yang masih dapat dikembangkan lebih lanjut diantaranya adalah notifikasi untuk blok atau kamar penuh, notifikasi untuk kamarkamar yang tidak memenuhi syarat penggunaan, dan sistem pengambilan keputusan untuk pengembangan selanjutnya.

\section{KESIMPULAN}

Rancang bangun sistem informasi aset rumah Sakit umum GMIM Siloam Sonder, yang dimulai dari analisis, perancangan dan implementasi. Diharapkan dapat membantu rumah sakit dalam pengelolaan aset disetiap ruangan, dengan dukungan sistem informasi geografis yang dapat mempresentasikan letak setiap aset yang ada.

Sistem informasi ini masih dapat dikembangkan lebih lanjut dengan menggunakan rancangan basis data relasional yang selanjutnya dapat digunakan untuk pengambilan keputusan manajemen. Metode-metode pengambilan keputusan seperti Fuzzy, Cluster Analysis, dan Principle Componen dapat digunakan untuk kebutuhan ini. 


\section{UCAPAN TERIMAKASIH}

Penelitian ini merupakan bagian dari publikasi penelitian yang didanai oleh RISTEKDIKTI melalui skim Penelitian Terapan Unggulan Universitas (PTUPT) tahun anggaran 2019. Untuk itu kami mengucapkan terimakasih kepada MSI-FTI UKSW dan RISTEKDIKTI atas dukungannya sehingga penelitian ini dapat terlaksana.

\section{DAFTAR PUSTAKA}

[1] Fatma, F. dan J. Devitra, "Analisis dan Perancangan Sistem Informasi Manajemen Aset Berbasis Website Pada Biro Pengelolaan Barang Milik Daerah Setda Provinsi Jambi," vol. 4, no. 1, hal. 28-37, 2019.

[2] Tripathy A., L. Mishra, dan P. K. Patra, "A multi dimensional design framework for querying spatial data using concept lattice," 2010 IEEE 2nd Int. Adv. Comput. Conf. IACC 2010, hal. 394-399, 2010.

[3] Kadir A., Pengenalan Sistem Informasi Edisi Revisi, vol. 14, no. 28. 2014.

[4] Yuliani S. T., B. Sudarsono, dan A. P. Wijaya, "Aplikasi Sistem Informasi Geografis (Sig) Untuk Pemetaan Pasar Tradisional Di Kota Semarang Berbasis Web," J. Geod. Undip, vol. 5, no. 2, hal. 208-2016, 2016.

[5] Suseno A. dan R. T. Agus, Penggunaan Quantum GIS Dalam Sistem Informasi Geografis. 2012.

[6] JSON, "Pengenalan JSON," JSON.org. [Daring]. Tersedia pada: https://www.json.org/jsonid.html. [Diakses: 12-Sep-2019]. 